\title{
Hepatitis A outbreak in HIV-infected MSM and in PrEP-using MSM despite a high level of immunity, Lyon, France, January to June 2017
}

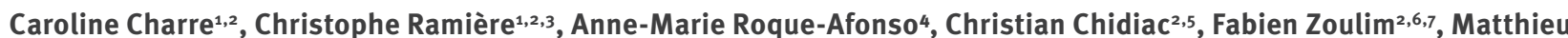

Godinot $^{8}$, Joseph Koffí5,6, Caroline Scholtès ${ }^{1,2,7}$, Jean-Michel Livrozet ${ }^{8}$, HAV Lyon Study Group9, Laurent Cotte ${ }^{5}$

1. Laboratoire de Virologie, Hôpital de la Croix-Rousse, Hospices Civils de Lyon, Lyon, France

2. Université de Lyon, Lyon, France

3. CIRI, International Center for Infectiology Research, Université de Lyon, Lyon, France

4. National reference centre for hepatitis A virus (Centre national de référence du virus de l'hépatite A), Virologie, Hôpital Paul Brousse, AP-HP, Villejuif, France

5. Service de maladie infectieuse et tropicale, Hôpital de la Croix Rousse, Hospices Civils de Lyon, Lyon, France

6. Service d'Hépatologie et de gastroentérologie, Hôpital de la Croix-Rousse, Hospices Civils de Lyon, Lyon, France

7. INSERM, U871, Lyon, France

8. Service de maladie infectieuse et tropicale, Hôpital Edouard Herriot, Hospices Civils de Lyon, Lyon, France

9. The members of the HAV Lyon Study Group are listed at the end of the article

Correspondence: Caroline Charre (caroline.charre@chu-lyon.fr)

Citation style for this article:

Charre Caroline, Ramière Christophe, Roque-Afonso Anne-Marie, Chidiac Christian, Zoulim Fabien, Godinot Matthieu, Koffi Joseph, Scholtès Caroline, Livrozet

Jean-Michel, HAV Lyon Study Group, Cotte Laurent. Hepatitis A outbreak in HIV-infected MSM and in PrEP-using MSM despite a high level of immunity, Lyon, France, January to June 2017. Euro Surveill. 2017;22(48): pii=17-00742. https://doi.org/10.2807/1560-7917.ES.2017.22.48.17-00742

Since 2016, an increase in the number of hepatitis A cases affecting mainly men who have sex with men (MSM) has been reported in low endemic countries in Europe. We calculated the attack rate in Lyon, France, in populations considered at high-risk: HIV-infected MSM and HIV-negative MSM receiving HIV pre-exposure prophylaxis (PrEP). In these populations, high level of immunity did not prevent the outbreak, indicating that vaccination should be reinforced, particularly in younger individuals.

Several outbreaks of acute hepatitis A among men who have sex with men (MSM) have been recently reported in different European countries [1-4]. Since the end of 2016, an important increase in the number of acute hepatitis A cases in MSM has been also notified in France through the national mandatory reporting system [5]. The aim of this study was to evaluate the proportion of hepatitis A virus (HAV)-susceptible individuals and the attack rate of acute hepatitis $A$ in HIV-infected MSM and in HIV-negative MSM receiving HIV pre-exposure prophylaxis (PrEP).

\section{Case definition and cohort description}

The infectious diseases department of the Hospices Civils de Lyon follows ca 3,800 HIV-infected patients per year, representing $94 \%$ of HIV-infected patients followed in the Rhône department. Additionally, 415 MSM who used PrEP in the Rhône department were followed in the infectious diseases department during the study period. All cases of acute hepatitis $A$ diagnosed in the Hospices Civils de Lyon virology laboratory between 1
January and 30 June 2017 were included. Diagnosis was based on the detection of serum HAV-specific IgM antibodies (ADVIA Centaur HAV assays, Siemens, Canada) along with elevated liver enzymes. HAV sequencing from IgM-positive samples was performed by the HAV national reference centre in Villejuif, France, as previously reported [6].

All 2,023 HIV-infected MSM and 415 PrEP users followed during the period were enrolled. Demographics (age, HIV status, PrEP use), HAV and hepatitis B virus (HBV) serological status, previous history of HAV infection and HAV vaccination history were retrieved from the clinical database and are compiled in the Table. The proportion of HAV-susceptible patients was determined based on medical, serological and vaccination history. Criteria for HAV immunity were: (i) past documented acute hepatitis A or (ii) past positive test for HAV total antibodies or (iii) administration of at least one dose of hepatitis A vaccine before January 2017. Evaluation of the attack rate in HIV-infected susceptible patients was determined by category of age. To take into account the patients with unknown HAV immune status, sensitivity analyses were performed assuming that patients with unknown HAV immune status were considered as susceptible (best case scenario), and that patients with unknown HAV immune status were considered as immune (worst case scenario). The hepatitis $A$ attack rate was not determined by category of age in PrEP users due to the limited number of cases. HAV cases in HIV-negative MSM not enrolled in the PrEP programme were not considered for the determination 


\section{FIGURE 1}

Epidemic curve of total hepatitis A cases, January-June 2017, Lyon, France $(n=46)$

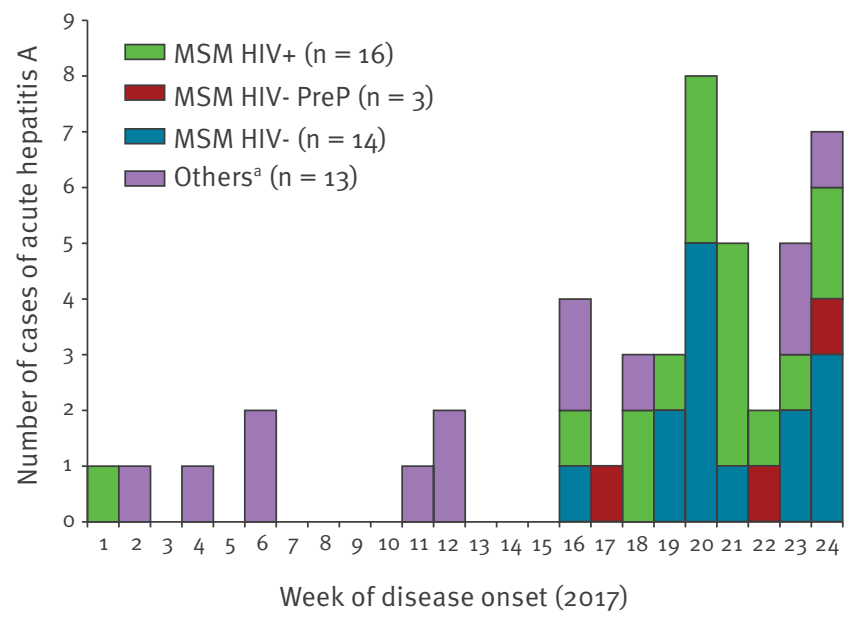

HIV +: HIV infected; HIV-: HIV negative; MSM: men who have sex with men; PrEP: pre-exposure prophylaxis

a The category 'Others' includes women, children and heterosexual men.

of the attack rate, since the denominator for this population is unknown. The study was approved by the local ethics committee.

\section{Description of the outbreak}

From 1 January 2017 to 30 June 2017, 46 cases of acute hepatitis $A$ were diagnosed in the laboratory (Figure 1) among whom 34 occurred between May and June. Two cases occurred in children under 15 years old. Among 44 adult cases, 38 were men (sex ratio M/F: 6.3); 33 were MSM, including $17 \mathrm{HIV}$-negative (among whom three were PrEP users) and 16 HIV-infected. Two cases in HIVinfected MSM who did not live in the Rhône department were excluded from the attack rate analysis. In all but one case occurring in MSM, sequencing identified one of the three epidemic strains circulating among MSM in many European countries [2-4]: 1a_VRD_521_2016 (UK/Spain; 18/33), 1a_RIVM_HAV16-090 (EuroPride; 12/33), and 1a_V16-25801 (2/33) (Table).

HIV-infected MSM were significantly older than PrEP users $(p<0.001)$. Among those with information available, the proportion of HAV-susceptible patients was not significantly different between groups (HIVinfected MSM: $26.6 \%$, PrEP users: $24.9 \%, p=0.48$ ). The attack rate irrespective of age was similar in HIVinfected MSM (best case scenario: $2 \%$; worst case scenario: $3.8 \%$ ) and in PrEP users (best case scenario: 2.7\%; worst case scenario: $3 \%$; Table). HAV susceptibility in patients with a known immune status was higher in patients aged 18-30 years, both among PrEP users (36\%) and in HIV-infected MSM (47\%) and decreased with age. The best and worst case scenario gave results that were close, except for the older HIVinfected group, in which a greater number of unknown
TABLE

Characteristics of HIV-infected MSM $(n=2,023)$ and MSM PrEP users $(n=415)$, January-June 2017, Lyon, France

\begin{tabular}{|c|c|c|c|c|}
\hline Characteristic & \multicolumn{2}{|c|}{$\begin{array}{l}\text { HIV-infected MSM } \\
\qquad(n=2,023)\end{array}$} & \multicolumn{2}{|c|}{$\begin{array}{l}\text { MSM PrEP } \\
\text { users } \\
(n=415)\end{array}$} \\
\hline $\begin{array}{l}\text { Age } \\
\text { median (IQR) }\end{array}$ & \multicolumn{2}{|c|}{$\begin{array}{c}49 \\
(40-57) \\
\end{array}$} & \multicolumn{2}{|c|}{$\begin{array}{c}36 \\
(29-44)\end{array}$} \\
\hline $\begin{array}{l}\text { CD4 cells count / mm }{ }^{3} \\
\text { median (IQR) }\end{array}$ & \multicolumn{2}{|c|}{$\begin{array}{r}676 \\
(515-857) \\
\end{array}$} & \multicolumn{2}{|c|}{ NA } \\
\hline \multirow{2}{*}{ Antiretroviral treatment } & $\mathrm{n}$ & $\%$ & \multirow{4}{*}{\multicolumn{2}{|c|}{ NA }} \\
\hline & $2,006 / 2,022^{\mathrm{a}}$ & 99.2 & & \\
\hline \multirow{2}{*}{$\begin{array}{l}\text { HIV viral load }<40 \text { copies/ } \\
\mathrm{mL}\end{array}$} & $\mathrm{n}$ & $\%$ & & \\
\hline & $815 / 1,963^{a}$ & 92.5 & & \\
\hline HBV status & $\mathrm{n}$ & $\%$ & $n$ & $\%$ \\
\hline Chronic hepatitis B & 67 & 3.3 & 1 & 0.2 \\
\hline Cured hepatitis & 693 & 34.3 & 18 & 4.3 \\
\hline Vaccinated & 1,041 & 51.5 & 349 & 84.1 \\
\hline Non immune & 175 & 8.6 & 31 & 7.5 \\
\hline Unknown & 47 & 2.3 & 16 & 3.9 \\
\hline HAV status & $\mathrm{n}$ & $\%$ & $n$ & $\%$ \\
\hline Immune & 1,219 & 60.3 & 305 & 73.5 \\
\hline - Vaccinated & 417 & 20.6 & 158 & 38.1 \\
\hline $\begin{array}{l}\text { - Previous history of } \\
\text { hepatitis A }\end{array}$ & 109 & 5.4 & 14 & 3.4 \\
\hline - Positive serology & 1,037 & 51.3 & 210 & 50.6 \\
\hline Non immune & 442 & 21.8 & 101 & $24 \cdot 3$ \\
\hline Unknown status & 362 & 17.9 & 9 & 2.2 \\
\hline \multicolumn{5}{|c|}{ Acute hepatitis A during outbreak (attack rate \%) } \\
\hline Best scenario & \multicolumn{2}{|c|}{2} & \multicolumn{2}{|c|}{2.7} \\
\hline Worst scenario & \multicolumn{2}{|l|}{3.8} & \multicolumn{2}{|c|}{3} \\
\hline \multicolumn{5}{|l|}{ Hepatitis A strain $(n=19)$} \\
\hline $\begin{array}{l}\text { 1a_RIVM_HAV16-90 } \\
\text { (EuroPride) }\end{array}$ & \multicolumn{2}{|l|}{6} & \multicolumn{2}{|l|}{0} \\
\hline $\begin{array}{l}\text { 1a_VRD_521_2016 (UK/ } \\
\text { Spain) }\end{array}$ & \multicolumn{2}{|l|}{10} & \multicolumn{2}{|c|}{2} \\
\hline $1 a \_V_{16}-25801$ & \multicolumn{2}{|l|}{ o } & \multicolumn{2}{|c|}{1} \\
\hline
\end{tabular}

IQR: interquartile range; MSM: men who have sex with men; NA: not applicable; PrEP: pre-exposure prophylaxis; UK: United Kingdom.

a Number of patients with information available for this variable.

status led to an increase in susceptibility in the best case scenario (Figure 2). The attack rate in HIV-infected MSM was highest in those aged 18-30 years (best case scenario: $5.2 \%$; worst case scenario: $6.3 \%$ ) and decreased with age to reach $0 \%$ in those aged 60 years or more.

\section{Discussion}

In high-income countries the prevalence of anti-HAV antibodies in the general population is usually low ( $<50 \%$ by the age of 30 years) [7] Therefore, the high proportion of susceptible individuals among adults 
Proportion of individuals susceptible to HAV and acute hepatitis A attack rate according to age, January-June 2017, Lyon, France

A. HIV-infected MSM $(n=2,023)$

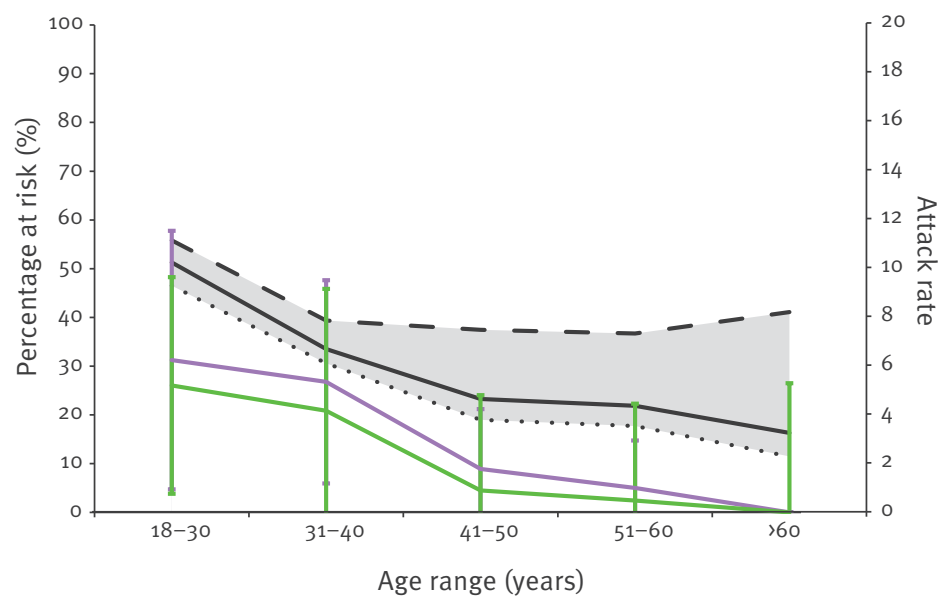

B. HIV-negative MSM receiving HIV PrEP ( $\mathrm{n}=415)$

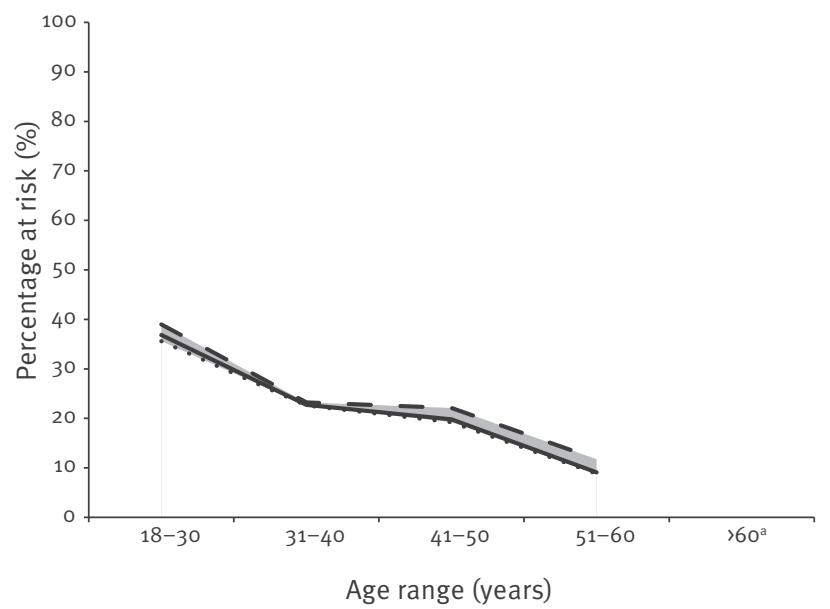

... Patients with unknown HAV immune status considered as immune

- Acute hepatitis A attack rate (best case scenario)

- Acute hepatitis A attack rate (worst case scenario)

HAV: hepatitis A virus; MSM: men who have sex with men; PrEP: pre-exposure prophylaxis.

${ }^{a}$ Number too small to calculate the percentage at risk.

Black lines: proportion of individuals susceptible to HAV.

Error bars: $95 \%$ confidence intervals.

could theoretically allow transmission, but usually hygiene measures limit the circulation of the virus and the risk of acquiring infection remains low. However, if $\mathrm{HAV}$ is introduced in groups at particular high-risk of transmission, outbreaks may occur according to level of immunity. Due to faeco-oral transmission during sexual activities, in particular bucco-anal, digital-anal, digitalrectal, and genito-oral activities following anal sex, MSM are at a high risk of HAV transmission. Moreover, as HAV transmission from sharing needles has also been described [8], intravenous injection of recreational drugs along with anal intercourse (also known as slamming) may increase the risk of HAV transmission in some groups of MSM. For these reasons, antiHAV vaccination is routinely recommended in France in HIV-infected MSM and PrEP users [9], contributing to a high level of immunity compared with the general population. For example, in a recent survey, $78 \%$ of adults aged 20-29 years were susceptible to HAV, as opposed to $31 \%$ of HIV-infected MSM and $29 \%$ of PrEP users in the present study [10]. Nevertheless, this high level of immunity did not prevent HAV outbreak in the present study.

Between 1 January 2017 and 30 June 2017, 57 cases of acute hepatitis $A$ were notified through the mandatory reporting system in the Rhône department. Among these 57 cases, 46 were diagnosed in our laboratory, suggesting a satisfying representativeness of the cases analysed here for the overall outbreak in the department. As previously reported, the outbreak described here affected mainly MSM with a similar attack rate in HIV-positive MSM and PrEP users, suggesting a comparable transmissibility in both groups considered at high risk of transmission.

One limitation of the study is that HAV immune status remained unknown in $17.9 \%$ of HIV-infected MSM and in $2.2 \%$ of PrEP users. However, in the best case scenario sensitivity analysis attack rates were high, confirming that both populations were engaged in at-risk sexual behaviour, as previously described [11,12]. Another limitation is that HAV immune status was not systematically confirmed serologically. Moreover, a single dose of hepatitis $A$ vaccine may not be sufficient to provide immunity in a HIV-positive patients [13]. However, during the study period, no case of acute hepatitis A was reported in our centre among patients who received a single dose of vaccine.

Predictions from a modelling study suggested that population immunity must exceed $70 \%$ to prevent future person-to-person transmission of hepatitis $A$ virus among MSM [14]. According to this model, the 
immunity level in the study population should have conferred protection against HAV outbreaks. However, HAV-susceptibility was much higher in younger individuals, which is likely to explain the higher attack rate observed before 40 years of age. Additionally, differences in risk practices among age groups may also have influenced transmission of the virus and the attack rate.

As immunity threshold of $70 \%$ seems to be insufficient to prevent HAV outbreaks, it should be adjusted considering behavioural characteristics, socio-demographic characteristics, and different age structures. Promotion of HAV vaccination should be reinforced, especially in young MSM who are at high risk of HAV transmission.

\section{Members of the HAV Lyon Study Group}

Hôpital de la Croix Rousse, Lyon: C. Chidiac, L. Cotte, J. Koffi, P. Miailhes, T. Ferry, F. Zoulim, F. Bailly, S. Radenne, M. Maynard-muet, P. Lack, K. Vandevoorde, G. Ouziel, M. Levrero, D. Poinsot, M. O'brien, A. Louf-durier, V. Escuret, I. Schuffenecker, M.A. Trabaud, C. Scholtès, C. Ramière, C. Achard, C. Charre.

Hôpital Edouard Herriot, Lyon: J.M. Livrozet, M. Godinot, D. Makhloufi, J. Dumortier, C.A. Durel, A. Hot, Y. Khennouf.

\section{Conflict of interest}

None declared.

\section{Authors' contributions}

Caroline Charre, Christophe Ramière, Caroline Scholtes performed laboratory diagnostics.

Anne-Marie Roque Afonso performed sequencing data analysis.

Christian Chidiac, Fabien Zoulim, Matthieu Godinot, Joseph Koffi, Jean-Michel Livrozet, Laurent Cotte provided clinical care.

Caroline Charre, Christophe Ramière, Laurent Cotte analysed the data and drafted the manuscript.

All authors reviewed the manuscript before submission.

Members of the HAV study group contributed to the acquisition of the clinical or biological data, revised the work, and approved the submitted version.

\section{References}

1. World Health Organization (WHO). Hepatitis A outbreaks mostly affecting men who have sex with men - European Region and the Americas. Geneva: WHO; 7 Jun 2017. Available from: http://www.who.int/csr/don/o7-june-2017-hepatitis-a/ en/

2. Werber D, Michaelis K, Hausner M, Sissolak D, Wenzel J, Bitzegeio J, et al. Ongoing outbreaks of hepatitis A among men who have sex with men (MSM), Berlin, November 2016 to January 2017 - linked to other German cities and European countries. Euro Surveill. 2017;22(5):30457. https://doi. org/10.2807/1560-7917.ES.2017.22.5.30457 PMID: 28183391
3. Beebeejaun K, Degala S, Balogun K, Simms I, Woodhall SC, Heinsbroek E, et al. Outbreak of hepatitis A associated with men who have sex with men (MSM), England, July 2016 to January 2017. Euro Surveill. 2017;22(5):30454. https://doi. org/10.2807/1560-7917.ES.2017.22.5.30454 PMID: 28183392

4. Freidl GS, Sonder GJ, Bovée LP, Friesema IH, van Rijckevorsel GG, Ruijs WL, et al. Hepatitis A outbreak among men who have sex with men (MSM) predominantly linked with the EuroPride, the Netherlands, July 2016 to February 2017. Euro Surveill. 2017;22(8):30468. https://doi.org/10.2807/1560-7917. ES.2017.22.8.30468 PMID: 28251892

5. Sante publique France. Epidémie d'hépatite A en France et en Europe - Point de situation au 11 septembre 2017. [Hepatitis A outbreak in France and in Europe - Situation as at 11 September 2017]. Paris: Sante publique France. [Accessed 27 Sep 2017]. French. Available from: http://invs. santepubliquefrance.fr/Dossiers-thematiques/Maladiesinfectieuses/Hepatites-virales/Hepatite-A/Points-d-actualite/ Epidemie-d-hepatite-A-en-France-et-en-Europe-Point-desituation-au-11-septembre-2017

6. Schwarz NG, Revillion M, Roque-Afonso AM, Dussaix E, Giraud $M$, Liberpre C, et al. A food-borne outbreak of hepatitis A virus (HAV) infection in a secondary school in Upper Normandy, France, in November 2006. Euro Surveill. 2008;13(22):18885. PMID: 18761959

7. Carrillo-Santisteve P, Tavoschi L, Severi E, Bonfigli S, Edelstein $M$, Byström E, et al. ECDC HAV Expert Panel. Seroprevalence and susceptibility to hepatitis A in the European Union and European Economic Area: a systematic review. Lancet Infect Dis. 2017;17(10):e306-19. https://doi.org/10.1016/S14733099(17)30392-4 PMID: 28645862

8. Spada E, Genovese D, Tosti ME, Mariano A, Cuccuini M, Proietti L, et al. An outbreak of hepatitis A virus infection with a high case-fatality rate among injecting drug users. J Hepatol. 2005;43(6):958-64. https://doi.org/10.1016/j. jhep.2005.06.012 PMID: 16143420

9. Morlat $P$, editor. Prise en charge médicale des personnes vivants avec le VIH. Recommandations du groupe d'experts. Actualisation 2017. [Medical management of people living with HIV. Recommendations from the group of experts. 2017 update]. Paris: la Documentation Française; 2017. [Accessed 24 Nov 2017]. French. Available from: https://cns.sante.fr//wpcontent/uploads/2017/07/experts-vih co-infections.pdf

10. Lepoutre A, Antona D, Fonteneau L, Halftermeyer-Zhou F, Baudon C, Dorléans F, et al. Séroprévalence des maladies à prévention vaccinale et de cinq autres maladies infectieuses en France. Résultats de deux enquêtes nationales 2008-2010. [Seroprevalence of vaccine-preventable diseases and five other infectious diseases in France. Results of two national surveys 2008-2010]. Bull Epidemiol Hebd (Paris). 2013; (41-42):526-34. French.

11. Molina J-M, Capitant C, Spire B, Pialoux G, Cotte L, Charreau I, et al. ANRS IPERGAY Study Group. On-Demand Preexposure Prophylaxis in Men at High Risk for HIV-1 Infection. N Engl J Med. 2015;373(23):2237-46. https://doi.org/10.1056/ NEJMoa1506273 PMID: 26624850

12. Velter A, Sauvage C, Saboni L, Sommen C, Alexandre A, Lydié $\mathrm{N}$, et al. Estimation de la prévalence du VIH chez les hommes ayant des relations sexuelles avec des hommes fréquentant les lieux de convivialité gay de cinq villes françaises - PREVAGAY 2015. [HIV prevalence estimate among men who have sex with men attending gay venues in five French cities - PREVAGAY 2015]. Bull Epidemiol Hebd (Paris). 2017; (18):347-54. French. Available from: http://invs.santepubliquefrance.fr/ beh/2017/18/2017_18_1.html

13. Phung B-C, Launay 0 . Vaccination against viral hepatitis of HIV-1 infected patients. Hum Vaccin Immunother. 2012;8(5):554-9. https://doi.org/10.4161/hv.19105 PMID: 22634451

14. Ali H, Regan DG, Guy RJ, Robertson P, Watchirs-Smith L, McNulty AM, et al. Increasing hepatitis A immunity in men who have sex with men in Sydney, 1996-2012. Vaccine. 2015;33(38):4745-7. https://doi.org/10.1016/j. vaccine.2015.01.090 PMID: 25720793

\section{License and copyright}

This is an open-access article distributed under the terms of the Creative Commons Attribution (CC BY 4.0) Licence. You may share and adapt the material, but must give appropriate credit to the source, provide a link to the licence, and indicate if changes were made.

This article is copyright of the authors, 2017. 